This is the peer reviewed version of the following article: Marzoli, D. , Havlíček, J. and Roberts, S. C. (2018), Human mating strategies: from past causes to present consequences. WIREs Cognitive Science, 9: e1456, which has been published in final form at https://doi.org/10.1002/wcs.1456. This article may be used for non-commercial purposes in accordance With Wiley Terms and Conditions for self-archiving. 


\author{
Article type: Advanced Review
}

\title{
Article title: HUMAN MATING STRATEGIES: FROM PAST CAUSES TO PRESENT CONSEQUENCES
}

Full name and affiliation; email address if corresponding author; any conflicts of interest

First author: Full name and affiliation; plus email address if corresponding author

[Daniele Marzoli*; Dept of Psychological Sciences, University of Chieti, Italy;

d.marzoli@unich.it]

Second author: Full name and affiliation; plus email address if corresponding author

[Jan Havlíček, Dept of Zoology, Charles University, Prague, Czech Republic]

Third author: Full name and affiliation; plus email address if corresponding author

[S. Craig Roberts, Division of Psychology, University of Stirling, UK]

\section{Abstract}

In both humans and non-human animals, mating strategies represent a set of evolutionary adaptations aimed at promoting individual fitness by means of reproduction with the best possible partners. Given this critical role, mating strategies influence numerous aspects of human life. In particular, between-sex divergence in the intensity of intrasexual competition could account for robust cross-cultural sex differences in psychology and behaviour (e.g., personality, psychiatric disorders, social behaviour, violence). Several other factors (including individual differences, relationship type and environment) affect - in an evolutionarily consistent manner - variation in mating strategy that individuals pursue (as one example, awareness of one's own attractiveness impinges on mating standards). Here we provide an overview of relevant theoretical frameworks and empirical evidence on variation in mating strategies. Given its multifaceted nature and intense research interest over several decades, this is a challenging task, and we highlight areas where further investigation is warranted in order to achieve a clearer picture and resolve apparent inconsistencies. However, we suggest that addressing outstanding questions using a variety of different methodological approaches, a deeper understanding of the cognitive representations involved in mating strategies is within reach. 


\section{THEORETICAL OVERVIEW}

In any given species, mating strategies represent a set of complex evolutionary adaptations aimed at promoting one's own reproductive success. In human terms, this means obtaining the maximum quantity of high-quality offspring (i.e., that themselves survive to adulthood and are reproductively successful) by means of coupling with the best possible opposite-sex partner or partners. In this regard, Darwin himself ${ }^{1}$ identified sexual selection, alongside natural selection, as a leading force in the evolution of human behaviour. Although some researchers do not distinguish sexual selection from natural selection, or consider it a special case of natural selection, sexual selection refers specifically to the emergence of traits that confer an advantage in competition for sexual partners, either because they are preferred by opposite-sex individuals (intersexual selection) or because they are associated with heightened odds of winning same-sex contests over mates or mating opportunities (intrasexual selection) ${ }^{2}$.

A crucial way in which sexual selection shaped human mating strategies is through the evolution of mate preferences, although it should be stressed that the goal-directed and problem-solving nature of any behavioural strategy does not necessarily imply any conscious awareness of the goal or contribution to decision-making ${ }^{3}$. The expression of mate preference is likely to be of central importance given its crucial influence on the likelihood to solve several mating-related problems, including choice of a fertile and compatible mate, ensuring sufficient high-quality parental care $)^{4}$. However, mating strategies cannot be reduced simply to mate selection, but also involve additional sets of behaviours that either relate to intersexual selection (such as displays to enhance selection by high-quality potential partners, propensity to engage in casual sex) or intrasexual selection (such as direct competition over mates, mate poaching, mate guarding, and competitor derogation).

Parental investment theory as proposed by Trivers ${ }^{5}$ is a particularly fruitful theoretical framework in which to understand variation in mating strategies. According to parental investment theory, the relative investment in offspring by males and females is a key variable in sexual selection. In species where one sex invests considerably more than the other, the less investing sex will compete to attract members of the more investing sex. In most species, females invest more in offspring and are the choosier sex, whereas males invest less and compete more over reproductively available females. In large part, this accounts for the fact - already noted by Darwin ${ }^{1}$ - that sexually selected traits are often more complex and elaborate in males (the reverse is true in species where males are the more investing sex). In species where both sexes provide significant investment, sexual selection operates to a similar degree on the two sexes, to the extent that both sexes exert choice based on attributes in the opposite sex. Even in such cases, interests of males and females will not entirely coincide. For example, internal fertilization leads to different vulnerabilities in each sex: females may still be relatively vulnerable to desertion whereas males are vulnerable to cuckoldry. Parental investment theory can help explain why sexual selection has fostered differences in mating strategies on various levels (i.e., between species, sexes and/or individuals). Indeed, female choice must take account of the quality of a potential mate's parental care only in species where males show some form of paternal investment. Furthermore, mate preferences are likely to be especially attuned to specific traits of potential partners that promote reproductive success in a species- 
specific manner. Finally, reproductive strategies may differ between the members of the same sex within the same species, for example more attractive individuals may afford to be choosier or less investing than less attractive counterparts).

Similar to other mammals, minimum (also coined obligatory) parental investment in humans shows relatively large sex differences. Female parental investment is primarily related to pregnancy and lactation, which are both energetically costly and time-consuming. In contrast, the minimum possible investment by males consists of fertilization. As the difference between female minimum and actual levels of parental effort is relatively small, there remains more variation in levels of investment among men, and thus greater variability in male mating strategies. Even so, the actual level of sex differences in parental investment is considerably smaller than that suggested by the obligatory minima, and men show various forms of parental care and investment in most human cultures. There are several possible explanations for this, including the possibility that biparental care is favoured because of human infant altriciality - paternal investment may therefore help to increase male reproductive success. Another hypothesised reason relates to predicting and detecting when a woman is fertile (Box 1), resulting in men who remain near a mate both for further mating opportunity and also paternal care. Thus, inconspicuous fertility and female internal fertilization may exert powerful influence on male mating behaviour, which can work in opposite ways according to conditional pros and cons. On one hand, paternity uncertainty might promote male mate desertion, while on the other, the motivation to increase paternity confidence could also help to promote male investment. As already highlighted by several authors ${ }^{\text {e.g. }}$, $, 6,7$, complex human sociality has led to the evolution of a multifaceted set of mating strategies that varies adaptively according to sex, temporal context, ecological factors and culture, as well as individual characteristics such as mate value and fertility status.

\section{Box 1. Concealed ovulation and monogamy}

It has been hypothesized that one of the main reproductive problems faced by men during human evolution is women's concealed ovulation, which strongly decreases paternity confidence 3 (although the proportion of children conceived by men other than women's social partner is much lower likely less than $5 \%^{8}$ - than previously reported). It has been proposed that concealed ovulation has fostered the evolution of long-term pair-bonding in men $^{9}$, because monopolizing access to a woman would strongly increase the probability of paternity, a selective advantage that is likely to outweigh the associated costs (e.g., time, effort, the loss of other copulation opportunities).

However, this topic remains controversial, for several reasons. First, it has been pointed out that the idea that women attempt to signal their ovulatory status (by wearing more revealing or sexier clothing at ovulation, for example $\mathrm{e}^{10}$ ) is at odds with the concept of functional advantages in concealing it ${ }^{11}$. Second, recent studies in which people rate stimuli of women collected during fertile and non-fertile phases of the menstrual cycle show that men (and women) can in fact discriminate some cues of estrus ${ }^{12-14}$, raising questions about how completely ovulation can be considered to be 'concealed'. Third, relatively inconspicuous ovulation is not exclusive to humans, being also observed in other primate species ${ }^{15}$. Indeed, current phylogenetic analyses indicate that 'non-advertised ovulation' might be the ancestral state in the last common human-chimpanzee ancestor, and what 
needs to be explained in adaptive terms is not 'concealment' but rather the development of conspicuous sexual swellings in the chimpanzee lineage ${ }^{16}$. Fourth, in line with this suggestion, the relative inconspicuousness of ovulatory changes in women coupled with the low rate of ovulation detection in men has led some researchers to argue that these might plausibly be interpreted as simple non-adaptive by-products of underlying hormonal changes across the cycle ${ }^{11}$. In other words, both the argument that concealed ovulation is a specific adaptation and consequent conjecture regarding adaptive functional explanations, such as through enhancing paternity confidence, are rendered unnecessary. Finally, it should also be noted that the supposed outcome of the proposed adaptation, exclusive monogamy, is not the only mating pattern adopted across human populations and cultures. We can also observe serial monogamy, polygyny, polyandry or polygynandry, levels of which appear to depend on both individual and ecological factors ${ }^{17-19}$.

In summary, the causal link between 'concealed' (or nearly concealed) ovulation and monogamy should be considered with caution, and it has been suggested that humans could be naturally inclined to polygyny, with monogamy arising from polygyny because of socioecological factors ${ }^{19}$. Nonetheless, it is undisputable that - at least when a polygynous mating strategy cannot be pursued successfully - monogamy can promote men's fitness in various ways, for instance by increasing offspring survival ${ }^{20}$ and increasing the likelihood of being selected by a desirable partner (e.g., because of attractive women's greater demand for cues of parenting proclivity and emotional commitment in a potential mate ${ }^{21}$ ).

\section{MATE PREFERENCES}

Mate preferences of men and women show many similarities. For example, both sexes prefer partners who are intelligent, kind, understanding and healthy, as well as partners who share their values, worldviews, intellectual level and personality characteristics ${ }^{6}$. Physical attractiveness is an important component, though not the only one. While the nature of the physical traits associated with attractiveness varies between sexes, sex-typical levels of attractiveness enhances reproductive success for both sexes ${ }^{22}$ and is generally associated with health ${ }^{23}$. However, mate preferences for physical attractiveness and other traits also exhibit certain differences that are consistent across culture and historical period ${ }^{24,25}$ and which arise as a consequence of facing different adaptive mating problems during human evolution ${ }^{3}$. The main source of such differences likely results from different levels of minimum parental investment ${ }^{5}$.

As a consequence, across cultures, men particularly favour partners showing cues of fertility such as youth and physical attractiveness, whereas women place relatively more emphasis on cues of provisioning ability such as good financial prospects and social status ${ }^{24}$. Relatively speaking, it appears that physical traits carry greater weight in determining female attractiveness to men, while status- and/or personality-related traits are relatively important in determining men's attractiveness to women ${ }^{26,27}$. For example, whereas men especially appreciate women's facial femininity (probably because of its link with reproductive value and health ${ }^{28}$ ), women do not show such a clear preference for men's facial masculinity, notwithstanding its association with certain desired traits 
such as dominance ${ }^{29}$. Furthermore, socioeconomic status enhances reproductive success for men more than for women ${ }^{30}$, likely also because high-status men marry younger women ${ }^{31}$.

In turn, mate preferences exert strong influences on several mating-related behaviours. For example, mate retention efforts among men are positively related to their partner's youth and physical attractiveness; among women, similar efforts are more related to the partner's income and ambition for status ${ }^{32}$. Similarly, the relative importance that men and women place, respectively, on a partner's sexual fidelity and willingness to invest ${ }^{24}$ might be responsible for men appearing especially concerned about a partner's sexual infidelity (given the risk of lowered paternity confidence), whereas women appear relatively concerned by the threat of emotional infidelity (given the risk of commitment and resource loss) ${ }^{33}$. We note that there is some debate surrounding this particular finding, particularly on whether the emergence of this sex difference in jealousyevoking events is attributable to methodological factors such as the use of forced-choice paradigms (e.g., see ${ }^{34,35}$ ). Further work is clearly needed in this regard.

\section{THE ROLE OF COMPETITIVE NICHES}

As previously stated, the different roles ancestral women and men played in parental care may provide a reasonable ground for sex-specific mate preferences, mate choice and mating strategies. For example, an obvious consequence of the different minimum parental investment provided by human males and females ${ }^{5}$ is that men can potentially exploit different mating strategies. One possible outcome of this is that men have higher reproductive variance than women and this is mostly explained by variation in mating system ${ }^{36}$. In societies where polygyny is more common, men are therefore likely to compete more heavily for mates than women. On the other hand, the relatively high investment of human males compared to most animal species can also result in some form of female competition ${ }^{37}$.

Moreover, it is at least plausible that the division of labour induced by their complementary roles in the ancestral economy led women and men to spend time in relatively different environments and to face different adaptive problems, thus promoting sex differences in some aspects of both anatomy and cognitive abilities. This may help to explain both sex differences in many tasks as well as sex-specific mate preference patterns ${ }^{38}$. Specifically, it has been proposed that many anatomical and behavioural sex differences were shaped by the division of labour, in particular regarding hunting.g., ${ }^{39}$. Socioeconomic and cultural factors further modulate sex differences in subsistence activities $^{40}$, although it has been suggested that socioeconomic factors play a relatively minor role compared to biological factors ${ }^{\mathrm{e} . \mathrm{g} .} 41$.

Several authors have cast doubt on the notion that division of labour was the main force leading to sex differences during human evolution, favouring instead an explanation based on male intrasexual competition e.g., 37,42 . For example Puts ${ }^{37}$ suggests that, given larger size and their ability to constrain women's choices, the dominant mode of sexual selection in men should be through intrasexual contests and the ensuing monopolization of women. There are several lines of support for the idea 
that male contests constituted a strong evolutionary force during human evolution, ranging from differences in physical aggressiveness between men and women to the richness of male facial and body displays that signal threat and fighting ability ${ }^{37,43-48}$. Puts ${ }^{37}$ describes three main ways in which male contests may have affected men's mating opportunities: i) coalitional aggression might have fostered the acquisition and defence of women against other groups of men; ii) men might have used force or the threat of force within their groups to acquire and defend one or more long-term partners or to obtain more short-term partners; and iii) contests might have contributed to the acquisition of resources, territory or status which serve to attract women. The development of a wide range of sexually dimorphic traits could thus be directly explained by intrasexual competition, whether it is body size or some aspects of cognitive ability. He also suggests that intrasexual competition could be indirectly important, through its effect on women's preference. In other words, men possessing certain traits (e.g. large size, muscularity, deep voice) could be preferred by women precisely because such traits reflect competitive ability, and this view seems to be corroborated by findings indicating that some male traits may not have evolved as primarily sexual ornaments. For example, masculine traits in male faces, bodies and voices are more associated with women's impressions of men's dominance than attractiveness ${ }^{49}$. Furthermore, while Miller ${ }^{50}$ argues that various aspects of human behaviour (e.g. language, art, morality) could have developed as a result of mutual mate preferences for cues of intelligence, creativity, and moral character, Puts ${ }^{37}$ suggests that the fact that such behaviours are displayed more conspicuously by men than by women $^{51}$ could be consistent with an additional role in intrasexual competition.

Regarding female strategies, Puts ${ }^{37}$ hypothesizes a crucial role for men's choice, suggesting that ancestral women competed to be the most attractive in order to lure the most desirable men, whether for genetic quality or for cues of higher investment. Consistent with this view, women lack traits designed for contest competition, but rather possess sex-typical anatomical traits that may have been selected by men's mate choice ${ }^{29,52}$; female-female competition usually involves more indirect strategies such as gossip, stigmatization and social exclusion ${ }^{53}$. In contrast, women's anatomical traits appear to cue general and reproductive health ${ }^{54}$.

Sex differences in competitive strategies are observed in a variety of contexts. Although use of violence is usually stigmatized in modern society, we can also observe other forms of competitive behaviour which can lead to increased status ${ }^{55}$. In this regard, sporting contests could have developed primarily in order to provide men with alternative and more socially acceptable arenas for intrasexual competition ${ }^{56}$, which could account for the greater interest of males in sports, and especially team sports and contact sports. In one diary study comparing men and women, men competed more in sports while women competed more about looking attractive ${ }^{57}$. Furthermore, men more than women base their feelings of self-worth on outdoing others in competitions, whereas women more than men base such feelings on being physically attractive ${ }^{58}$.

The relative weighting of attractiveness and status/dominance in the establishment of women's and men's intrasexual hierarchies is also reflected in the fact that observers selectively attend to attractive women and high-status/dominant men ${ }^{59}$. Consistently, women and men exhibiting sextypical sexually selected traits receive more consideration by public opinion and media. For example, media are biased toward male sports coverage $e^{60}$, and female athletes are too often evaluated in terms of appearance compared with male athletes ${ }^{61}$. The sexualized representation of women is not 
limited to the sport domain, but is widespread in the media ${ }^{62}$. Moreover, representations of the 'ideal' female body as unrealistically attractive and thin, and of the 'ideal' male body as exceedingly muscular, appears to contribute to specific concerns with weight loss and muscle gain in young women and men, respectively ${ }^{63}$. In this way, levels of intrasexual competition provide a useful perhaps the most informative - perspective by which to understand sex differences in physical exercise, cosmetic surgery, steroid use, eating disorders and a number of other psychopathological symptoms ${ }^{64}$. Furthermore, it corroborates the idea that an ancestral history of male contest competition could help to explain several adversities afflicting current society, such us war, homicide, criminality and bullying ${ }^{37}$. Sex differences in ancient competitive niches could also be responsible for a multitude of other, less detrimental effects, such as several personality differences between women and men. For example, the observation that men are on average more willing to take risks than women has implications for behavioural economics, such as differences in entrepreneurship ${ }^{65}$.

Of course, it is not possible to ascribe every sex difference observed in human behaviour to differences in competitive strategies. For example, female superiority in emotion perception is more likely due to women's responsibility for child-rearing throughout human evolutionary history ${ }^{66}$. Furthermore, empirical evidence indicates that both intra- and intersexual selection contributed to some sexually dimorphic traits of mating-related psychology and appearance. For instance, some male traits are both sexually attractive to women and intimidating to other men ${ }^{52}$, and women can also resort to intrasexual physical aggression when competing for desirable mates ${ }^{67}$. In this regard, there remains dispute about sex differences and similarities in human sexuality, notably regarding the extent to which the sexual interests and strategies of men and women diverge ${ }^{68}$. On the other hand, given that different mating strategies are expressed according to socio-ecological circumstances ${ }^{17-19}$ and that - when possible - males make use of their status in order to procure as many mates as possible ${ }^{69}$, the model proposed by Puts ${ }^{37}$ remains a valid framework for studying sex differences in mating strategies.

\section{EFFECTS OF MATE PREFERENCE OF ONE SEX ON BEHAVIOUR OF THE OPPOSITE SEX}

It can be assumed that, over evolutionary time, the mate preferences of one sex shaped the mating behaviour of the opposite sex ${ }^{4}$. Furthermore, if mate attraction is a major factor in intrasexual competition ${ }^{70,71}$, then individuals should be accurate in judging what members of the opposite sex seek in a potential mate ${ }^{72}$ and believe that possession of such traits will be useful in order to attract a partner ${ }^{73}$. Consistent with this, as an expected consequence of women's preference for men with resources, men are more likely than women to exhibit resources and related cues and to derogate potential sexual competitors by stating that their antagonists lack these qualities ${ }^{32,74}$. Similarly, as an expected consequence of men's preferences for attractive and sexually faithful women, women are more likely than men to enhance their appearance and to derogate potential sexual competitors by highlighting their antagonists' lower physical attractiveness or by labelling them as sexually promiscuous and unfaithful ${ }^{32,74}$.

According to Sexual Strategies Theory ${ }^{3}$, the use of deception is one logical consequence of competition to achieve and display traits desired by the opposite sex. For example, men might 
display cues of long-term interest in order to obtain casual sex, whereas women might emphasise cues of fidelity in order to obtain resource investment from men. On the other hand, both sexes are likely to have evolved psychological mechanisms to detect deception. Psychological mechanisms in men might be tuned to detect signs of infidelity, to focus on reliable predictors of infidelity (such as promiscuity), and to withdraw investment from children whose paternity is dubious. In women, psychological mechanisms might be especially tuned to detect the occurrence of deception in commitment displays, to focus on reliable predictors of long-term commitment, and to require considerable levels of commitment which are costly to fake (such as prolonged courtship) before consenting to sex. In fact, research shows that men are more likely than women to exaggerate their commitment and financial resources, whereas women are more likely than men to exaggerate their physical attributes ${ }^{75}$. Similarly, levels of concern (or upset) about specific forms of deception varies according to each sex's favoured sexual strategy, women being more upset by deception about resources and commitment and men by deception about sexual access ${ }^{76}$.

Men and women also appear to be threatened by different qualities of their same-sex rivals. Men report greater distress when a rival who is interested in their partner surpasses them on resources and strength, while women are similarly concerned by more physically attractive rivals ${ }^{77}$. Men and women exhibit more jealousy when rivals are dominant or physically attractive, respectively ${ }^{33}$. Similarly, men's mate guarding is specifically triggered when they are confronted with rivals with superior economic resources or prospects, whereas women's mate guarding is specifically triggered when they are confronted with more physically attractive rivals ${ }^{78}$. Consistent with such findings, the two sexes exhibit different mate retention tactics, with men using resource display more than women, and women using appearance enhancement more than men ${ }^{32}$.

\section{FACTORS AFFECTING MATING STRATEGIES}

Although we argue that mating strategies are shaped by selection over human evolutionary history, this does not imply that they are fixed and inflexible, nor are they shaped only by sex-specific selection pressures. Indeed, the adaptive function of mating strategies is enhanced by their plasticity, which allows for condition-dependent expression and adjustment to a variety of social and contextual factors ${ }^{6,7,17}$. In this section, we review some of these key factors.

\section{Individual differences}

Individual differences are known to affect mating strategies of both men and women. In this regard, a key concept in evolutionary psychology is sociosexual orientation, a notional continuum in which individuals vary from considering sexual activity only within long-lasting and committed romantic relationships (restricted sociosexual orientation) to being open to brief and uncommitted sexual encounters (unrestricted sociosexual orientation) ${ }^{79}$. An individual's position on this continuum might equate to propensity for long-term versus short-term mating as envisaged by Sexual Strategies Theory ${ }^{3}$. Men report to be less restricted than women across several cultures ${ }^{17}$. Simpson and Gangestad ${ }^{80}$ found that sociosexual orientation is associated with evolutionarily consistent mate preferences: restricted individuals are likely to prefer kind, affectionate, responsible and loyal mates, whereas unrestricted individuals are likely to prefer physically and sexually attractive mates. 
Sociosexual orientation is also linked to several other instances of mating-related individual differences, such as variation in personality traits, attachment styles, and gender roles ${ }^{81}$.

Given some doubt that a single unitary dimension might accurately reflect individual differences in sociosexuality, a revised formulation ${ }^{82}$ of the initial sociosexual orientation index has been proposed, which includes three separate components: behaviour (i.e., the quantity of previous short-term sexual encounters), attitude (i.e., the evaluative disposition toward uncommitted sex), and desire (i.e., the dispositional motivation to invest efforts into short- versus long-term mating tactics). Another criticism of the original concept of sociosexual orientation is that restricted and unrestricted mating behaviours are considered along a single bipolar continuum. It has been argued that a multidimensional measure that independently assesses interest and openness to both short- and long-term mating strategies would be more useful, especially because individuals might pursue both tactics simultaneously ${ }^{83,84}$. Indeed, accounting for both short- and long-term orientations allows a better understanding of both between-sex and within-sex variations in mating psychology, revealing that i) women and men differ more in their orientation toward casual sex than in their orientation toward long-term committed relationships; ii) within each sex, short- and long-term orientations correlate differently with other theoretically relevant variables; and iii) important sex differences are observed when correlating individual characteristics (e.g., personality traits, attachment styles, mate preferences) and either short- or long-term orientation ${ }^{83,84}$.

One's mate value is another important predictor of individual difference in mating strategies and mate preferences. Mate value can be defined as one's attractiveness to members of the choosing sex, relative to those others against whom one is compared ${ }^{6,85}$. It has been proposed that individuals with high mate value should be more able to pursue their sex-specific preferred strategy compared to same-sex individuals with low mate value ${ }^{7,22,86}$. Thus, and in line with what we have discussed above, men with significant resources (i.e. with high mate value) show stronger preferences for physically attractive women than men with relatively low mate value; physically attractive women also show stronger preferences for men with resources. For example, in analysis of personal advertisements, individuals who offer traits sought by the opposite sex are also more demanding of certain traits in potential respondents, compared with those not offering such traits ${ }^{87}$. In experimental tests, women who rate themselves as attractive show stronger preferences for masculinity in male faces judged for a long-term relationship ${ }^{88}$, while men who perceive themselves as attractive show stronger preferences for femininity in female faces judged for a short-term relationship ${ }^{86}$. Similarly, women with low waist-to-hip ratio (perceived as an attractive body shape) exhibit stronger preferences for apparent health and related cues in male faces ${ }^{89}$. Higher demand characteristics in individuals with high mate value could explain why high-status men are more likely to attract a great number of partners, including wives, concubines and lovers ${ }^{69}$, and why more symmetrical men and men with high testosterone levels (i.e., those of putatively high genetic quality) are more likely to have extra-pair copulations ${ }^{90}$.

There is also increasing evidence that several personality traits are associated with mate preferences. In men, sensation-seeking and systemizing are positively related to preferences for feminine female faces ${ }^{91,92}$. In women, stronger preferences for masculine male faces are positively associated with their extraversion, impulsivity, and empathizing ${ }^{92,93}$. Although no direct evidence is currently available, it has been suggested that sensation-seeking in men and extraversion in women 
might in fact be markers of mate value, leading to heightened demand characteristics for healthrelated cues in opposite-sex faces. Similar effects could be exerted not only by sex-typical physical characteristics (as reported above), but also by sex-typical psychological traits (such as empathizing in women and systemizing in men $^{92}$ ).

It should also be stressed that individual strategic preferences vary according to current circumstances, regardless of an individual's sociosexual orientation, mate value and personality. This can be most easily demonstrated by studies in which social context is experimentally manipulated. For example, enhancing someone's perception of their own mate value through positive statements by others can shift men's attitudes toward casual sex ${ }^{94}$. A different manipulation of self-perceived mate value, through visual exposure to a number of attractive same-sex individuals, decreases women's self-rated attractiveness and also their preferences for masculine male faces, whereas exposure to unattractive same-sex individuals elicits the opposite effects ${ }^{95}$. In social competition between men, a 'win' elicits stronger preferences for feminine female faces ${ }^{96}$ and greater sexual interest in women ${ }^{97}$ compared with a 'loss'. These kinds of changes may be relatively temporary, but others may have longer effects when linked to more durable social circumstances. For example, different life stages might lend themselves to exploitation of different strategies, such as the adoption of a short-term mating outlook to assess one's own current mate value, as well as the current mating market ${ }^{3}$, at times when this is uncertain. This might explain relative focus on shortterm mating in adolescents. Alternatively, a major change in personal circumstances, such as following a shift in relationship or social status, might warrant a recalibration of one's own mate value, again fostering a period of preference for short-term mating. Evidence also suggests that life changes affect mate preferences in evolutionarily plausible ways. Men's preferences for feminine female faces decline with ageing ${ }^{98}$, and similarly women's preferences for masculine and sexy male faces decline with ageing and pregnancy ${ }^{99,100}$. As described below, such adjustments in mating strategies could be linked to hormonal changes following marriage, divorce, or parenthood.

\section{Hormone levels}

A great deal of research has demonstrated associations between hormone levels and both mate preferences and mating strategies. First, exposure to androgens in the developing brain may be the main influence on the emergence of universal sex differences in mate preferences, cognition and behaviour ${ }^{38}$, and the role of testosterone and oestrogen surges in shaping development of secondary sexual characteristics and sexual desire are well-established. But hormones continue to play a role into adulthood. In men, for example, sexual behaviour appears closely associated with testosterone levels, which are positively related to preference for short-term mating strategies and to mating over parenting effort. It is now well-established that entering marriage or long-term committed relationships, and embarking on fatherhood, appear to reduce testosterone levels ${ }^{101-103}$. Interestingly, reductions following these commitments appear weaker in men who continue to show a tendency for extra-pair sexual interests ${ }^{104,105}$. These findings indicate that inter-individual differences in hormone levels are associated both with major changes in life stages and with individual differences in mating strategy and effort. 
Physical attractiveness is also influenced by sex-typical hormone markers, such as facial masculinity in men and facial femininity in women ${ }^{28,106}$, but individual variation in such traits would normally reflect early developmental exposure to sex hormones and are relatively fixed by adulthood. Much more subtle and transient effects on appearance and attractiveness are seen in changes across a woman's menstrual cycle, such as increasing facial attractiveness around the fertile phase (see also Box 1), presumably determined by changes in estradiol and progesterone ${ }^{12,13}$. Cyclic hormone fluctuations also calibrate both women's sexual desire and behaviour. For example, estradiol and progesterone show positive and negative effects, respectively, on self-reported sexual desire ${ }^{107}$, women appear to wear clothing to attract men during the ovulatory phase ${ }^{10}$, and their likelihood of wearing red at this time (another proposed courtship tactic) increases in line with the estradiol-toprogesterone ratio ${ }^{108}$ (although - as noted by Havlicek et al. ${ }^{11}$ - this is at odds with the idea of concealed ovulation; see Box 1).

Hormonal levels also appear to influence preferences. In men, preference for facial femininity in women is stronger when their salivary testosterone is high ${ }^{109}$ and is positively correlated with their average salivary cortisol ${ }^{110}$. In women, estradiol levels correlate positively with preferences for faces of men with higher testosterone concentrations ${ }^{111,112}$, early follicular testosterone levels are positively associated with preferences for male facial masculinity ${ }^{113}$, and fertility is associated with a stronger preference for masculinity across the ovulatory cycle (comparing fertile and non-fertile phases ${ }^{106}$ ) and across age (comparing fertile and non-fertile women or pre- and post-menopausal women $\left.{ }^{100,114}\right)$, although it is worth noting that some recent, well-powered studies do not find some of these effects ${ }^{115}$.

\section{Relationship type}

The type of relationship sought (i.e., long-term vs. short-term) appears to be another factor affecting mate preferences. On the whole, it appears that men are more inclined than women towards shortterm mating opportunities, and women are more inclined toward long-term mating commitment compared to men ${ }^{3,7,17}$. Evidence for this includes findings that men desire larger numbers of sexual partners than women in any given future time interval (ranging from the next month to lifetime) ${ }^{3}$. In view of the constraints imposed on women by pregnancy, lactation and menopause, such a pattern is a likely consequence of the fact that the potential reproductive benefit of mating with numerous partners is much lower for women because, differently from men, they cannot as easily increase the number of offspring by having sex with several mates.

Despite this, and in light of the individual differences and hormonal effects reviewed above, Sexual Strategies Theory ${ }^{3}$ incorporates the possibility for individuals of both sexes to strategically pursue both long- and short-term mating strategies. The expression of mate preferences will vary accordingly, which leads to specific predictions regarding the nature of benefits that men and women can gain at different times. For men, the main benefit of short-term mating would be the possibility of inseminating more than one woman, and in this mating context men seem to desire and prefer cues of sexual availability in potential sexual partners. In contrast, the main benefit of long-term mating would be the possibility of monopolizing a woman's reproductive capacity, leading to preference for partners who are young and physically attractive (i.e., showing cues of high 
reproductive value), as well as sexually loyal and faithful (i.e., showing cues of paternity confidence). For women, the main benefit of long-term mating is continuous access to a partner's resources and parental investment, so women should prefer long-term mates who exhibit high ambition, industry, earning capacity, education and generosity (i.e., showing cues of ability and willingness to invest). Women can also benefit from short-term mating (including extra-pair mating) through the possibility of gaining genetic quality in potential offspring ${ }^{90}$, and in this mating context women seem to desire men possessing phenotypic cues of good genes, such as attractiveness and masculinity. The predictions of Sexual Strategies Theory ${ }^{3}$ have been supported by a number of independent studies $^{116-118}$.

At this point, we add some caveats to the necessarily brief description of Sexual Strategies Theory provided above. First, the mating preferences of each sex in each context must be considered as relative rather than absolute. For example, in both contexts women desire men possessing cues of both resources and good genes; what differs between the two contexts is the relative weighting attributed to the different cues. Second, the distinction between long- and short-term mating should be considered more as representing the opposite poles of a continuum rather than as a pure dichotomy: the adoption of either depends on a complex cocktail of social and ecological conditions ${ }^{7}$ and individuals can even pursue mixed mating strategies, further illustrating the adaptive plasticity of mating strategies ${ }^{4}$. Third, we have classified relationships according to their temporal axis (i.e., long-term vs. short-term) as originally suggested by Sexual Strategies Theory, but this can be misleading. For instance, some relationships may be short because the qualities of one of the partners are not satisfying for the other partner, even though both parties were initially motivated to pursue a long-term relationship. Similarly, some long-lasting relationships, such as in the case of friends with benefits, share more commonalities with short-term mating due to their low level of commitment ${ }^{119}$. Thus, we think that in many cases a classification based on commitment (i.e., committed vs. uncommitted) might be more suitable because it more precisely captures the underlying mating psychology. Finally, it should be noted that men are almost as demanding as women for committed and long-term relationships ${ }^{3,120}$, that is when substantial investment is made by both parties. On the contrary, for uncommitted or short-term relationships, men's standards appear somewhat relaxed while women's standards remain relatively exacting, because of the differential minimum investment in offspring ${ }^{5}$. In summary, mate preferences match the specific reproductive problems faced by each sex in a particular mating context.

\section{Situational and environmental variables}

Mate preferences can also be strongly affected by a range of situational and environmental variables. For example, individuals living in areas with high pathogen prevalence place greater importance on a mate's physical attractiveness, a trait associated with pathogen resistance ${ }^{121}$. Furthermore, a cross-cultural study showed that women's preference for men's facial masculinity - a trait thought to be linked to good health - is negatively correlated with average national health ${ }^{122}$, although an interesting alternative explanation is that masculinity preferences could be associated more with national income inequality than health, because of associations between inequality and level of male intrasexual competition ${ }^{123}$. Men's preference for women's facial masculinity is also 
negatively correlated with national health, perhaps because of greater relative weighting in men's preferences for cues of resource-holding potential compared with fecundity. In summary, relaxed selection for cues of competitive ability and resource-holding potential lead to more feminine faces being considered more attractive in both men and women, signifying a shift in the locally prevalent benefits associated with mate choice ${ }^{124}$.

Environmental factors, and geographical location in particular, can also influence mate preferences for traits other than physical appearance. For example, urban-dwelling women (where the cost of living is high) demand more resources and fewer emotional qualities in a prospective mate within their personal advertisements ${ }^{125}$. Importantly, Eagly and Wood ${ }^{126}$ observed that, across cultures, women's access to resources and power inversely predicts the extent to which women emphasize a potential spouse's earning capacity (see also ${ }^{127}$ ). In keeping with such findings, people from less socioeconomically developed countries rate the possession of characteristics linked to resource acquisition as more important in a long-term partner, and consider mutual attraction/love as less important than individuals from more developed countries ${ }^{128}$. Similarly, Zentner and Mitura ${ }^{129}$ found that gender differences in adaptive mate preferences decline proportionally with increases in national gender equality (but see ${ }^{130}$ for a methodological criticism).

Besides mate preferences, environment can affect mating strategies in a host of other ways. For example, familial stressors - and father absence during early childhood in particular - are associated in both sexes with several physiological and psychological events, such as behavioural problems, earlier pubertal onset, and more precocious and indiscriminate reproductive behaviour ${ }^{131}$. These findings are consistent with the hypothesized crucial influence of the early local environment in shaping adult reproductive strategies, mainly by means of attachment styles ${ }^{132}$. In this regard, there is some evidence of a positive link between insecure attachment and short-term mating strategies ${ }^{133}$. Another important factor is the local operational sex ratio (i.e., the relative number of reproductively available men and women). In cultures with a male-biased ratio, men compete more intensely and the mating system is driven by female preference for long-term, monogamous mating. On the contrary, in female-biased cultures, women compete relatively intensely and the mating system is driven by male preference for short-term, more promiscuous mating ${ }^{17,134}$. A related example is that polygynous mating is more common in areas with high pathogen prevalence, where women's preference for men's genetic quality may be more pronounced ${ }^{17,135}$.

The studies described above are based on correlational evidence. Cross-population comparisons are informative, but may be explained by other variables than those to which the effects are attributed. However, the kinds of conclusion reached above are also supported by experimental evidence. For example, women's mate preferences for markers of either good genes or high paternal investment shift when participants are primed with cues of pathogen prevalence and resource scarcity, respectively ${ }^{136}$. Similarly, exposure to visual cues of environmental pathogens increases preferences for mates exhibiting health-related traits, so that women prefer more masculine and symmetrical male faces and men prefer more feminine and symmetrical female faces ${ }^{137}$. Exposure to visual cues of direct male-male competition, violence and wealth ${ }^{138}$ also increases women's preferences for masculine male faces. Furthermore, experimental manipulation of perceived sex ratio causes individuals to recalibrate their sociosexual orientation ${ }^{139}$. Finally, when participants are required to indicate the relative importance of different traits of an ideal partner under various hypothetical 
scenarios, wealth and dominance are more valued in a poverty scenario and in a violent scenario, respectively, compared to the other scenarios ${ }^{140}$. These examples are powerful as they provide conclusive experimental evidence to support the interpretations reached by correlational analyses of cross-country trends; together, both approaches provide convincing and converging support for the context-contingent adaptive flexibility of human mating strategies.

\section{ACTUAL MATING BEHAVIOUR}

As argued above, if mate preferences have evolved, it must be because they have positively influenced the outcome of actual mating decisions during human evolution (see also ${ }^{6}$ ). We should therefore expect to see that mate preferences correlate positively with observed mating behaviour. Several lines of evidence support this. For example, women's preference for male facial masculinity as measured in laboratory tests positively correlated with their actual partner's facial masculinity ${ }^{49}$. A rich source of such evidence can be found in studies of 'lonely hearts' advertisements, in which people explicitly list self-attributes they think will attract partners and state characteristics they seek in a partner. Studies of response rates to personal ads show that women are more likely to answer to men describing themselves as tall, well educated, financially secure, and older, whereas men are less likely to answer to women describing themselves as tall, heavy, well-educated and older e.g." 141,142 . Moreover, the advertising of physical attractiveness positively affects response rates to women's ads more than response rates to men's ads, whereas the opposite is true for the advertising of socioeconomic status ${ }^{141}$. It is also important to note that both women and men in their personal ads offer those traits which are sought by the opposite sex ${ }^{143}$.

An alternative line of evidence relates to data on married couples. Women who are physically attractive - and thus with high mate value - tend to marry men with higher social status and more resources compared to less attractive women ${ }^{144}$. Across different periods and cultures, women tend to marry men who are older than they are (likely because men's status and resources usually increase with age), and the age difference between brides and grooms increases with men's age $\mathrm{e}^{24,145}$. Moreover, brides' youthfulness correlates with their grooms' status and wealth ${ }^{31}$. Buss ${ }^{6}$ suggests that a man's occupational status may be the best predictor of the attractiveness of the woman he marries, in line with the idea that men and women of high mate value - namely, those possessing status and attractiveness, respectively - are mutually attracted and actually select each other.

Furthermore, the shift of female mate preferences toward cues linked to underlying genetic quality of partners ('good genes') when pursuing an uncommitted or short-term mating strategy (whose extreme consequences could be observed when seeking a sperm donor ${ }^{146}$ ) can be exemplified by the case of attractiveness and symmetry (which is deemed to reflect developmental stability, that is the ability to withstand environmental events and genetic stressors which can determine asymmetry in faces and bodies), and thus phenotypic quality and health ${ }^{147}$. Indeed, more symmetric and attractive men have more extra-pair partners and are chosen as extra-pair partners more often than less symmetric, more unattractive men ${ }^{90}$. 
Finally, however, it is worth noting that preferences and actual mate choice decisions do not always correspond exactly. This does not imply that preferences are not meaningful, as there are several possible reasons for such a mismatch. First, the chance to attract highly desired potential partners are constrained by the exacting preferences exerted by such individuals ${ }^{21,85}$, who might not reciprocate interest (e.g., as in the case of assortative mating by attractiveness ${ }^{148}$ ) or might not be selected because of their ability to attract potential rivals ${ }^{149}$. Moreover, only a few members of each sex possess to a great extent most of the traits (i.e., those exerting positive effects on the fitness of mate and offspring) desired by the opposite sex, and many individuals must compete for such highly desirable potential partners (which could explain the cross-cultural ubiquity of mate poaching tactics $\left.{ }^{150}\right)$. There is a solution to such problems, however, which is that we possess the cognitive flexibility needed to adjust to such situations. For example, there is experimental evidence that people modulate mating standards according to their own perceived mate value, as well as to make trade-offs among their ideals when needed ${ }^{85}$. People also adjust personal preferences in response to social pressure from parents and $\mathrm{kin}^{151}$.

\section{CONCLUSION}

Far from being exhaustive, the present review nonetheless highlights how mating strategies are complex and important influences on various aspects of human life. It has been claimed de. $^{\text {. } 37,42,64}$ that between-sex divergence in intrasexual competition could account for most universal sex differences in psychology and behaviour, so that recent proposals ${ }^{\text {e.g., } 152}$ that sexual selection contributes heavily to shape actual society appear convincing. This view also links intrasexual competition and seemingly unrelated behaviours, such as understanding sex differences in risk taking ${ }^{153}$, drinking games ${ }^{154}$ and generosity ${ }^{155}$ through the lens of mating displays. Nonetheless, interpretation of the evidence is subject to ongoing debate, particularly in areas such as the evolution of concealed ovulation, sex differences in promiscuity, and the relative choosiness of men and women especially in long-term partnerships. Indeed, even meta-analyses on the same issue can lead scholars with different theoretical stances to draw opposite conclusions (as in the case of menstrual cycle effects on women's mate preferences $\left.{ }^{156,157}\right)$.

In our opinion, further insights will be gained through converging evidence from different data sources, such as studies investigating the effects of ecological factors, individual differences and experimental manipulations on mating strategies and mate preferences. In this regard, research relating the effects of pathogen prevalence, pathogen disgust and exposure to pathogen cues on expression of mate preferences represents an excellent case. The greater importance placed on a mate's attractiveness and associated physical traits in areas with poor health and higher pathogen prevalence ${ }^{121,122}$ indicates that mate preferences shift adaptively according to local ecological conditions. Consistent effects of exposure to pathogen cues ${ }^{136,137}$ strongly suggest that individuals' reactions to external stimuli - rather than genetic factors - could account for cross-cultural differences in mate preferences. The positive correlation between individuals' pathogen disgust and their preferences for sex-typical and attractive opposite-sex faces and bodies ${ }^{\text {e.g., }} 110,158$ seems to demonstrate that, besides actual circumstances, one's own interpretation of the world can modulate mate preferences accordingly. Indeed, disease concerns might foster the avoidance of 
potentially unhealthy individuals, also affecting - at least in women - the balance between perceived benefits (high genetic quality) and costs (low parental investment) of selecting a masculine mate. The involvement of complex - and largely implicit - cognitive evaluations is corroborated by studies showing stronger preferences for healthy-appearing male faces in women with experience of current or previous cold ${ }^{159}$ and stronger preferences for feminine female faces in men with higher salivary cortisol, a biomarker for immunosuppression ${ }^{110}$. Few research questions related to human mating strategies have been addressed with a comparable multifaceted approach, but we suggest that this is precisely what is required in future investigations of mating cognition.

\begin{tabular}{|c|c|}
\hline 1 & $\begin{array}{l}\text { Darwin, C. (1859). On the origins of species by means of natural selection. London: } \\
\text { Murray. }\end{array}$ \\
\hline 2 & Andersson, M. (1994). Sexual Selection. Princeton, NJ: Princeton University Press. \\
\hline 3 & $\begin{array}{l}\text { Buss, D. M., \& Schmitt, D. P. (1993). Sexual strategies theory: An evolutionary } \\
\text { perspective on human mating. Psychological Review, } 100 \text { (2), 204. DOI: } \\
10.1037 / 0033-295 X .100 .2 .204\end{array}$ \\
\hline 4 & Buss, D. M. (2006). Strategies of human mating. Psihologijske Teme, 15 (2), 239-260. \\
\hline 5 & $\begin{array}{l}\text { Trivers, R. L. (1972). Parental investment and sexual selection. In B. Campbell (Ed.), } \\
\text { Sexual selection and the descent of man 1871-1971 (pp. 136-179). Chicago: Aldine. }\end{array}$ \\
\hline 6 & $\begin{array}{l}\text { Buss, D. M. (2008). Evolutionary psychology: The new science of the mind, 3rd Ed. } \\
\text { Boston: Allyn \& Bacon. }\end{array}$ \\
\hline 7 & $\begin{array}{l}\text { Gangestad, S. W., \& Simpson, J. A. (2000). The evolution of human mating: Trade-offs } \\
\text { and strategic pluralism. Behavioral and Brain Sciences, } 23 \text { (04), 573-587. DOI: } \\
\text { 10.1017/S0140525X0000337X }\end{array}$ \\
\hline 8 & $\begin{array}{l}\text { Anderson, K. (2006). How well does paternity confidence match actual } \\
\text { paternity?. Current Anthropology, 47(3), 513-520. DOI: } 10.1086 / 504167\end{array}$ \\
\hline 9 & $\begin{array}{l}\text { Alexander, R. D., \& Noonan, K. M. (1979). Concealment of ovulation, parental care, } \\
\text { and human social evolution. In N. A. Chagnon \& W. Irons (Eds.), Evolutionary biology } \\
\text { and human social behavior: An anthropological perspective (pp. 436-453). North } \\
\text { Scituate, MA: Duxbury Press. }\end{array}$ \\
\hline 10 & $\begin{array}{l}\text { Haselton, M. G., Mortezaie, M., Pillsworth, E. G., Bleske-Rechek, A., \& Frederick, D. A. } \\
\text { (2007). Ovulatory shifts in human female ornamentation: Near ovulation, women dress } \\
\text { to impress. Hormones and Behavior, } 51 \text { (1), 40-45. DOI: 10.1016/j.yhbeh.2006.07.007 }\end{array}$ \\
\hline 11 & $\begin{array}{l}\text { Havlíček, J., Cobey, K. D., Barrett, L., Klapilová, K., \& Roberts, S. C. (2015). The } \\
\text { spandrels of Santa Barbara? A new perspective on the peri-ovulation }\end{array}$ \\
\hline
\end{tabular}




\begin{tabular}{|c|c|}
\hline & paradigm. Behavioral Ecology, 26 (5), 1249-1260. DOI: 10.1093/beheco/arv064 \\
\hline 12 & $\begin{array}{l}\text { Puts, D. A., Bailey, D. H., Cárdenas, R. A., Burriss, R. P., Welling, L. L., Wheatley, J. } \\
\text { R., \& Dawood, K. (2013). Women's attractiveness changes with estradiol and } \\
\text { progesterone across the ovulatory cycle. Hormones and Behavior, 63 (1), 13-19. DOI: } \\
\text { 10.1016/j.yhbeh.2012.11.007 }\end{array}$ \\
\hline 13 & $\begin{array}{l}\text { Roberts, S. C., Havlicek, J., Flegr, J., Hruskova, M., Little, A. C., Jones, B. C., Perrett, } \\
\text { D. I., \& Petrie, M. (2004). Female facial attractiveness increases during the fertile } \\
\text { phase of the menstrual cycle. Proceedings of the Royal Society of London B: Biological } \\
\text { Sciences, } 271 \text { (Suppl 5), S270-S272. DOI: 10.1098/rsbl.2004.0174 }\end{array}$ \\
\hline 14 & $\begin{array}{l}\text { Haselton, M. G., \& Gildersleeve, K. (2011). Can men detect ovulation? Current } \\
\text { Directions in Psychological Science, } 20 \text { (2), 87-92. DOI: 10.1177/0963721411402668 }\end{array}$ \\
\hline 15 & $\begin{array}{l}\text { Sillén-Tullberg, B., \& Moller, A. P. (1993). The relationship between concealed } \\
\text { ovulation and mating systems in anthropoid primates: A phylogenetic analysis. } \\
\text { American Naturalist, } 141 \text { (1), 1-25. }\end{array}$ \\
\hline 16 & $\begin{array}{l}\text { Duda, P., \& Zrzavý, J. (2013). Evolution of life history and behavior in Hominidae: } \\
\text { Towards phylogenetic reconstruction of the chimpanzee-human last common } \\
\text { ancestor. Journal of Human Evolution, } 65(4), 424-446 . \text { DOI: } \\
\text { 10.1016/j.jhevol.2013.07.009 }\end{array}$ \\
\hline 17 & $\begin{array}{l}\text { Schmitt, D. P. (2005). Sociosexuality from Argentina to Zimbabwe: A 48-nation study } \\
\text { of sex, culture, and strategies of human mating. Behavioral and Brain Sciences, } 28 \\
\text { (02), 247-275. DOI: } 10.1017 / \text { S0140525X05000051 }\end{array}$ \\
\hline 18 & $\begin{array}{l}\text { Roberts, S. C., \& Havlíček, J. (2013). Humans are dunnocks, not peacocks: on cause } \\
\text { and consequence of variation in human mating strategies. Psychological Inquiry, } 24 \\
\text { (3), 231-236. DOI: 10.1080/1047840X.2013.817299 }\end{array}$ \\
\hline 19 & $\begin{array}{l}\text { Chapais, B. (2013). Monogamy, strongly bonded groups, and the evolution of human } \\
\text { social structure. Evolutionary Anthropology: Issues, News, and Reviews, 22 (2), 52-65. } \\
\text { DOI: } 10.1002 / \text { evan. } 21345\end{array}$ \\
\hline 20 & $\begin{array}{l}\text { Hill K, Hurtado AM. 1996. Ache life history: The ecology and demography of a foraging } \\
\text { people. Hawthorne, NY: Aldine de Gruyter. }\end{array}$ \\
\hline 21 & $\begin{array}{l}\text { Buss, D. M., \& Shackelford, T. K. (2008). Attractive women want it all: Good genes, } \\
\text { economic investment, parenting proclivities, and emotional commitment. Evolutionary } \\
\text { Psychology, } 6 \text { (1), 134-146. DOI: } 10.1177 / 147470490800600116\end{array}$ \\
\hline 22 & $\begin{array}{l}\text { Rhodes, G., Simmons, L. W., \& Peters, M. (2005). Attractiveness and sexual behavior: } \\
\text { Does attractiveness enhance mating success? Evolution and Human Behavior, } 26 \text { (2), } \\
\text { 186-201. DOI: } 10.1016 / \text { j.evolhumbehav.2004.08.014 }\end{array}$ \\
\hline
\end{tabular}




\begin{tabular}{|c|c|}
\hline 23 & $\begin{array}{l}\text { Nedelec, J. L., \& Beaver, K. M. (2014). Physical attractiveness as a phenotypic marker } \\
\text { of health: An assessment using a nationally representative sample of American } \\
\text { adults. Evolution and Human Behavior, 35(6), 456-463. DOI: } \\
\text { 10.1016/j.evolhumbehav.2014.06.004 }\end{array}$ \\
\hline 24 & $\begin{array}{l}\text { Buss, D. M. (1989). Sex differences in human mate preferences: Evolutionary } \\
\text { hypotheses tested in } 37 \text { cultures. Behavioral and Brain Sciences, 12(01), 1-14. DOI: } \\
10.1017 / S 0140525 X 00023992\end{array}$ \\
\hline 25 & $\begin{array}{l}\text { Buss, D. M., Shackelford, T. K., Kirkpatrick, L. A., \& Larsen, R. J. (2001). A half century } \\
\text { of mate preferences: The cultural evolution of values. Journal of Marriage and } \\
\text { Family, 63 (2), 491-503. DOI: 10.1111/j.1741-3737.2001.00491.x }\end{array}$ \\
\hline 26 & $\begin{array}{l}\text { Feingold, A. (1990). Gender differences in effects of physical attractiveness on } \\
\text { romantic attraction: A comparison across five research paradigms. Journal of } \\
\text { Personality and Social Psychology, } 59(5), 981-993 . \text { DOI: } 10.1037 / 0022-3514.59 .5 .981\end{array}$ \\
\hline 27 & $\begin{array}{l}\text { Kniffin, K. M., \& Wilson, D. S. (2004). The effect of nonphysical traits on the } \\
\text { perception of physical attractiveness: Three naturalistic studies. Evolution and Human } \\
\text { Behavior, } 25(2), 88-101 . \text { DOI: } 10.1016 / \text { S1090-5138(04)00006-6 }\end{array}$ \\
\hline 28 & $\begin{array}{l}\text { Smith, M. L., Perrett, D. I., Jones, B. C., Cornwell, R. E., Moore, F. R., Feinberg, D. R., } \\
\text { Boohtroyd, L. G., Durrani, S. J., Stirrat, M. R., Whiten, S., et al. (2006). Facial } \\
\text { appearance is a cue to oestrogen levels in women. Proceedings of the Royal Society of } \\
\text { London B: Biological Sciences, } 273 \text { (1583), 135-140. DOI: } 10.1098 / \mathrm{rspb} .2005 .3296\end{array}$ \\
\hline 29 & $\begin{array}{l}\text { Perrett, D. I., Lee, K. J., Penton-Voak, I., Rowland, D., Yoshikawa, S., Burt, D. M., } \\
\text { Henzi, S. P., Castles, D. L., \& Akamatsu, S. (1998). Effects of sexual dimorphism on } \\
\text { facial attractiveness. Nature, } 394 \text { (6696), 884-887. DOI: } 10.1038 / 29772\end{array}$ \\
\hline 30 & $\begin{array}{l}\text { Nettle, D., \& Pollet, T. V. (2008). Natural selection on male wealth in humans. The } \\
\text { American Naturalist, } 172 \text { (5), 658-666. DOI: } 10.1086 / 591690\end{array}$ \\
\hline 31 & $\begin{array}{l}\text { Voland, E., \& Engel, C. (1990). Female choice in humans: a conditional mate selection } \\
\text { strategy of the Krummhörn women (Germany, 1720-1874). Ethology, } 84 \text { (2), 144-154. } \\
\text { DOI: } 10.1111 / \text { j.1439-0310.1990.tb00791.x }\end{array}$ \\
\hline 32 & $\begin{array}{l}\text { Buss, D. M., \& Shackelford, T. K. (1997). From vigilance to violence: mate retention } \\
\text { tactics in married couples. Journal of personality and social psychology, } 72 \text { (2), } 346 . \\
\text { DOI: } 10.1037 / 0022-3514.72 .2 .346\end{array}$ \\
\hline 33 & $\begin{array}{l}\text { Brase, G. L., Caprar, D. V., \& Voracek, M. (2004). Sex differences in responses to } \\
\text { relationship threats in England and Romania. Journal of Social and Personal } \\
\text { Relationships, 21(6), 763-778. DOI: 10.1177/0265407504047836 }\end{array}$ \\
\hline 34 & $\begin{array}{l}\text { Bendixen, M., Kennair, L. E. O., \& Buss, D. M. (2015). Jealousy: Evidence of strong sex } \\
\text { differences using both forced choice and continuous measure paradigms. Personality }\end{array}$ \\
\hline
\end{tabular}




\begin{tabular}{|c|c|}
\hline & and Individual Differences, 86, 212-216. DOI: 10.1016/j.paid.2015.05.035 \\
\hline 35 & $\begin{array}{l}\text { DeSteno, D., Bartlett, M. Y., Braverman, J., \& Salovey, P. (2002). Sex differences in } \\
\text { jealousy: Evolutionary mechanism or artifact of measurement? Journal of personality } \\
\text { and social psychology, } 83 \text { (5), 1103. DOI: } 10.1037 / 0022-3514.83 .5 .1103\end{array}$ \\
\hline 36 & $\begin{array}{l}\text { Brown, G. R., Laland, K. N., \& Mulder, M. B. (2009). Bateman's principles and human } \\
\text { sex roles. Trends in Ecology \& Evolution, } 24 \text { (6), 297-304. DOI: } \\
\text { 10.1016/j.tree.2009.02.005 }\end{array}$ \\
\hline 37 & $\begin{array}{l}\text { Puts, D. A. (2010). Beauty and the beast: Mechanisms of sexual selection in } \\
\text { humans. Evolution and Human Behavior, } 31 \text { (3), 157-175. DOI: } \\
\text { 10.1016/j.evolhumbehav.2010.02.005 }\end{array}$ \\
\hline 38 & $\begin{array}{l}\text { Ellis, L. (2011). Evolutionary neuroandrogenic theory and universal gender differences } \\
\text { in cognition and behavior. Sex Roles, } 64(9-10), 707-722 \text {. DOI: } 10.1007 / \mathrm{s} 11199-010- \\
9927-7\end{array}$ \\
\hline 39 & $\begin{array}{l}\text { Lancaster, J. B., \& Kaplan, H. S. (2009). The endocrinology of the human adaptive } \\
\text { complex. In P. T. Ellison, \& P. B. Gray (Eds.), Endocrinology of Social Relationships } \\
\text { (pp. 95-118). Cambridge, MA: Harvard. }\end{array}$ \\
\hline 40 & $\begin{array}{l}\text { Wood, W., \& Eagly, A. H. (2002). A cross-cultural analysis of the behavior of women } \\
\text { and men: Implications for the origins of sex differences. Psychological Bulletin, } 128 \\
\text { (5), 699-727. DOI: dx.doi.org/10.1037/0033-2909.128.5.699 }\end{array}$ \\
\hline 41 & $\begin{array}{l}\text { Lippa, R. A. (2010). Sex differences in personality traits and gender-related } \\
\text { occupational preferences across } 53 \text { nations: Testing evolutionary and social- } \\
\text { environmental theories. Archives of Sexual Behavior, } 39(3), 619-636 . \text { DOI: } \\
\text { 10.1007/s10508-008-9380-7 }\end{array}$ \\
\hline 42 & $\begin{array}{l}\text { Ecuyer-Dab, I., \& Robert, M. (2004). Have sex differences in spatial ability evolved } \\
\text { from male competition for mating and female concern for survival? Cognition, } 91 \text { (3), } \\
\text { 221-257. DOI: } 10.1016 / \text { j.cognition.2003.09.007 }\end{array}$ \\
\hline 43 & $\begin{array}{l}\text { Archer, J. (2004). Sex Differences in Aggression in Real-World Settings: A Meta- } \\
\text { Analytic Review. Review of General Psychology, 8(4), 291-322. DOI: 10.1037/1089- } \\
\text { 2680.8.4.291 }\end{array}$ \\
\hline 44 & $\begin{array}{l}\text { Archer, J. (2009). Does sexual selection explain human sex differences in } \\
\text { aggression? Behavioral and Brain Sciences, 32 (3-4), 249-266. DOI: } \\
\text { 10.1017/S0140525X09990951 }\end{array}$ \\
\hline 45 & $\begin{array}{l}\text { Třebický, V., Havlíček, J., Roberts, S. C., Little, A. C., \& Kleisner, K. (2013). Perceived } \\
\text { aggressiveness predicts fighting performance in mixed-martial-arts } \\
\text { fighters. Psychological Science, 24(9), 1664-1672. DOI: } 10.1177 / 0956797613477117\end{array}$ \\
\hline
\end{tabular}




\begin{tabular}{|c|c|}
\hline 46 & $\begin{array}{l}\text { Little, A. C., Třebický, V., Havlíček, J., Roberts, S. C., \& Kleisner, K. (2015). Human } \\
\text { perception of fighting ability: facial cues predict winners and losers in mixed martial } \\
\text { arts fights. Behavioral Ecology, 26(6), 1470-1475. DOI: 10.1093/beheco/arv089 }\end{array}$ \\
\hline 48 & $\begin{array}{l}\text { Sell, A., Cosmides, L., Tooby, J., Sznycer, D., von Rueden, C., \& Gurven, M. (2009). } \\
\text { Human adaptations for the visual assessment of strength and fighting ability from the } \\
\text { body and face. Proceedings of the Royal Society of London B: Biological Sciences, } 276 \\
\text { (1656), 575-584. DOI: } 10.1098 / \text { rspb.2008.1177 }\end{array}$ \\
\hline 49 & $\begin{array}{l}\text { DeBruine, L. M., Jones, B. C., Little, A. C., Boothroyd, L. G., Perrett, D. I., Penton- } \\
\text { Voak, I. S., Cooper, P. A., Penke, L., Feinberg, D. R., \& Tiddeman, B. P. (2006). } \\
\text { Correlated preferences for facial masculinity and ideal or actual partner's } \\
\text { masculinity. Proceedings of the Royal Society of London B: Biological Sciences, } 273 \\
\text { (1592), 1355-1360. DOI: 10.1098/rspb.2005.3445 }\end{array}$ \\
\hline 50 & $\begin{array}{l}\text { Miller, G. F. (2000). The mating mind: How sexual choice shaped the evolution of } \\
\text { human nature. New York: Doubleday. }\end{array}$ \\
\hline 51 & $\begin{array}{l}\text { Miller, G. F. (2001). Precis of: The Mating Mind: How Sexual Choice Shaped the } \\
\text { Evolution of Human Nature. Psycoloquy, } 12(008), 1 .\end{array}$ \\
\hline 52 & $\begin{array}{l}\text { Barber, N. (1995). The evolutionary psychology of physical attractiveness: Sexual } \\
\text { selection and human morphology. Ethology and Sociobiology, 16(5), 395-424.DOI: } \\
10.1016 / 0162-3095(95) 00068-2\end{array}$ \\
\hline 53 & $\begin{array}{l}\text { Campbell, A. (2004). Female competition: Causes, constraints, content, and } \\
\text { contexts. Journal of Sex Research, } 41 \text { (1), 16-26. DOI: } 10.1080 / 00224490409552210\end{array}$ \\
\hline 54 & $\begin{array}{l}\text { Jasieńska, G., Ziomkiewicz, A., Ellison, P. T., Lipson, S. F., \& Thune, I. (2004). Large } \\
\text { breasts and narrow waists indicate high reproductive potential in women. Proceedings } \\
\text { of the Royal Society B: Biological Sciences, } 271 \text { (1545), 1213-1217. DOI: } \\
10.1098 / \text { rspb.2004.2712 }\end{array}$ \\
\hline 55 & $\begin{array}{l}\text { Ellis, L. (2004). Sex, status, and criminality: A theoretical nexus. Social Biology, } 51 \text { (3- } \\
\text { 4), 144-160. DOI: } 10.1080 / 19485565.2004 .9989091\end{array}$ \\
\hline 56 & $\begin{array}{l}\text { Lombardo, M. P. (2012). On the evolution of sport. Evolutionary Psychology,10(1), 1- } \\
\text { 28. DOI: } 10.1177 / 147470491201000101\end{array}$ \\
\hline 57 & $\begin{array}{l}\text { Cashdan, E. (1998). Are men more competitive than women? British Journal of Social } \\
\text { Psychology, 37(2), 213-229. DOI: 10.1111/j.2044-8309.1998.tb01166.x }\end{array}$ \\
\hline 58 & $\begin{array}{l}\text { Zeigler- Hill, V., Clark, C. B., \& Pickard, J. D. (2008). Narcissistic Subtypes and } \\
\text { Contingent Self- Esteem: Do All Narcissists Base Their Self- Esteem on the Same } \\
\text { Domains? Journal of Personality, 76(4), 753-774. DOI: 10.1111/j.1467- } \\
6494.2008 .00503 . x\end{array}$ \\
\hline
\end{tabular}




\begin{tabular}{|c|c|}
\hline 59 & $\begin{array}{l}\text { Maner, J. K., DeWall, C. N., \& Gailliot, M. T. (2008). Selective attention to signs of } \\
\text { success: social dominance and early stage interpersonal perception. Personality \& } \\
\text { Social Psychology Bulletin, } 34 \text { (4), 488-501. DOI: } 10.1177 / 0146167207311910\end{array}$ \\
\hline 60 & $\begin{array}{l}\text { Eastman, S. T., \& Billings, A. C. (2000). Sportscasting and Sports Reporting: The } \\
\text { Power of Gender Bias. Journal of Sport \& Social Issues, 24(2), 192-213. DOI: } \\
10.1177 / 0193723500242006\end{array}$ \\
\hline 61 & $\begin{array}{l}\text { Billings, A. C., Halone, K. K., \& Denham, B. E. (2002). "Man, that was a pretty shot": } \\
\text { An analysis of gendered broadcast commentary surrounding the } 2000 \text { men's and } \\
\text { women's NCAA final four basketball championships. Mass Communication \& Society, } 5 \\
\text { (3), 295-315. DOI: } 10.1207 / S 15327825 M C S 0503 \text { 4 }\end{array}$ \\
\hline 62 & $\begin{array}{l}\text { Collins, R. L. (2011). Content analysis of gender roles in media: Where are we now } \\
\text { and where should we go? Sex Roles, 64(3), 290-298. DOI: 10.1007/s11199-010- } \\
9929-5\end{array}$ \\
\hline 63 & $\begin{array}{l}\text { Ricciardelli, L. A., McCabe, M. P., Holt, K. E., \& Finemore, J. (2003). A biopsychosocial } \\
\text { model for understanding body image and body change strategies among } \\
\text { children. Journal of Applied Developmental Psychology, 24 (4), 475-495. DOI: } \\
\text { 10.1016/S0193-3973(03)00070-4 }\end{array}$ \\
\hline 64 & $\begin{array}{l}\text { Del Giudice, M. (2014). An evolutionary life history framework for psychopathology. } \\
\text { Psychological Inquiry, 25(3-4), 261-300. DOI: 10.1080/1047840X.2014.884918 }\end{array}$ \\
\hline 65 & $\begin{array}{l}\text { Bönte, W., \& Piegeler, M. (2013). Gender gap in latent and nascent entrepreneurship: } \\
\text { driven by competitiveness. Small Business Economics, } 41 \text { (4), 961-987. DOI: } \\
\text { 10.1007/s11187-012-9459-3 }\end{array}$ \\
\hline 66 & $\begin{array}{l}\text { Hampson, E., van Anders, S. M., \& Mullin, L. I. (2006). A female advantage in the } \\
\text { recognition of emotional facial expressions: Test of an evolutionary } \\
\text { hypothesis. Evolution and Human Behavior, 27(6), 401-416. DOI: } \\
\text { 10.1016/j.evolhumbehav.2006.05.002 }\end{array}$ \\
\hline 67 & $\begin{array}{l}\text { Campbell, A. (1995). A few good men: Evolutionary psychology and female adolescent } \\
\text { aggression. Ethology and Sociobiology, } 16(2), 99-123 . \text { DOI: } 10.1016 / 0162- \\
\text { 3095(94)00072-F }\end{array}$ \\
\hline 68 & $\begin{array}{l}\text { Stewart-Williams, S., \& Thomas, A. G. (2013). The ape that thought it was a peacock: } \\
\text { Does evolutionary psychology exaggerate human sex differences? Psychological } \\
\text { Inquiry, } 24(3), 137-168 . \text { DOI: } 10.1080 / 1047840 X .2013 .804899\end{array}$ \\
\hline 69 & $\begin{array}{l}\text { Betzig, L. (1986). Despotism and differential reproduction: A Darwinian view of history. } \\
\text { New York: Aldine de Gruyter. }\end{array}$ \\
\hline 70 & $\begin{array}{l}\text { Walters, S., \& Crawford, C. B. (1994). The importance of mate attraction for } \\
\text { intrasexual competition in men and women. Ethology and Sociobiology, 15(1), 5-30. }\end{array}$ \\
\hline
\end{tabular}




\begin{tabular}{|c|c|}
\hline & DOI: $10.1016 / 0162-3095(94) 90025-6$ \\
\hline 71 & $\begin{array}{l}\text { Ainsworth, S. E., \& Maner, J. K. (2012). Sex begets violence: Mating motives, social } \\
\text { dominance, and physical aggression in men. Journal of Personality and Social } \\
\text { Psychology, } 103 \text { (5), 819-829. DOI: } 10.1037 / \mathrm{a} 0029428\end{array}$ \\
\hline 72 & $\begin{array}{l}\text { Clark, S. C., Dover, A. M., Geher, G., \& Presson, P. K. (2005). Perceptions of self and } \\
\text { of ideal mates: Similarities and differences across the sexes. Current Psychology, } 24 \\
\text { (3), 180-202: DOI: } 10.1007 / \text { s12144-005-1021-x }\end{array}$ \\
\hline 73 & $\begin{array}{l}\text { Li, N. P. (2007). Mate Preference Necessities in Long-and Short-Term Mating: People } \\
\text { Prioritize in Themselves What Their Mates Prioritize in Them. Acta Psychologica } \\
\text { Sinica, } 39(3), 528-535 .\end{array}$ \\
\hline 74 & $\begin{array}{l}\text { Buss, D. M., \& Dedden, L. A. (1990). Derogation of competitors. Journal of Social and } \\
\text { Personal Relationships, 7(3), 395-422. DOI: } 10.1177 / 0265407590073006\end{array}$ \\
\hline 75 & $\begin{array}{l}\text { Tooke, W., \& Camire, L. (1991). Patterns of deception in intersexual and intrasexual } \\
\text { mating strategies. Ethology and Sociobiology, } 12 \text { (5), 345-364. DOI: 10.1016/0162- } \\
\text { 3095(91)90030-T }\end{array}$ \\
\hline 76 & $\begin{array}{l}\text { Haselton, M. G., Buss, D. M., Oubaid, V., \& Angleitner, A. (2005). Sex, lies, and } \\
\text { strategic interference: The psychology of deception between the sexes. Personality } \\
\text { and Social Psychology Bulletin, } 31 \text { (1), 3-23. DOI: } 10.1177 / 0146167204271303\end{array}$ \\
\hline 77 & $\begin{array}{l}\text { Buss, D. M., Shackelford, T. K., Choe, J. A. E., Buunk, B. P., \& Dijkstra, P. (2000). } \\
\text { Distress about mating rivals. Personal Relationships, 7(3), 235-243. DOI: } \\
\text { 10.1111/j.1475-6811.2000.tb00014.x }\end{array}$ \\
\hline 78 & $\begin{array}{l}\text { Buss, D. M. (2002). Human mate guarding. Neuroendocrinology Letters, } 23 \text { (Suppl 4), } \\
\text { 23-29. }\end{array}$ \\
\hline 79 & $\begin{array}{l}\text { Simpson, J. A., \& Gangestad, S. W. (1991). Individual differences in sociosexuality: } \\
\text { evidence for convergent and discriminant validity. Journal of Personality and Social } \\
\text { Psychology, } 60 \text { (6), 870-883. DOI: } 10.1037 / 0022-3514.60 .6 .870\end{array}$ \\
\hline 80 & $\begin{array}{l}\text { Simpson, J. A., \& Gangestad, S. W. (1992). Sociosexuality and romantic partner } \\
\text { choice. Journal of Personality, } 60 \text { (1), 31-51. DOI: } 10.1111 / \text { j.1467- } \\
\text { 6494.1992.tb00264.x }\end{array}$ \\
\hline 81 & $\begin{array}{l}\text { Simpson, J. A., Wilson, C. L., \& Winterheld, H. A. (2004). Sociosexuality and romantic } \\
\text { relationships. In J. H. Harvey, A. Wenzel, \& S. Sprecher (Eds.), Handbook of Sexuality } \\
\text { in Close Relationships (pp. 87-112). Mahwah, NJ: Erlbaum. }\end{array}$ \\
\hline 82 & $\begin{array}{l}\text { Penke, L., \& Asendorpf, J. B. (2008). Beyond global sociosexual orientations: a more } \\
\text { differentiated look at sociosexuality and its effects on courtship and romantic } \\
\text { relationships. Journal of Personality and Social Psychology, 95(5), 1113-1135. DOI: }\end{array}$ \\
\hline
\end{tabular}




\begin{tabular}{|c|c|}
\hline & $10.1037 / 0022-3514.95 .5 .1113$ \\
\hline 83 & $\begin{array}{l}\text { Holtzman, N. S., \& Strube, M. J. (2012). Above and beyond short-term mating, long- } \\
\text { term mating is uniquely tied to human personality. Evolutionary Psychology, } 11 \text { (5), } \\
\text { 1101-1129. DOI: } 10.1177 / 147470491301100514\end{array}$ \\
\hline 84 & $\begin{array}{l}\text { Jackson, J. J., \& Kirkpatrick, L. A. (2007). The structure and measurement of human } \\
\text { mating strategies: Toward a multidimensional model of sociosexuality. Evolution and } \\
\text { Human Behavior, } 28(6), 382-391 . \text { DOI: } 10.1016 / \text { j.evolhumbehav.2007.04.005 }\end{array}$ \\
\hline 85 & $\begin{array}{l}\text { Edlund, J. E., \& Sagarin, B. J. (2010). Mate value and mate preferences: An } \\
\text { investigation into decisions made with and without constraints. Personality and } \\
\text { Individual Differences, } 49 \text { (8), 835-839. DOI: } 10.1016 / \text { j.paid.2010.07.004 }\end{array}$ \\
\hline 86 & $\begin{array}{l}\text { Little, A. C., Jones, B. C., Feinberg, D. R., \& Perrett, D. I. (2014). Men's strategic } \\
\text { preferences for femininity in female faces. British Journal of Psychology, 105(3), 364- } \\
\text { 381. DOI: } 10.1111 \text { /bjop.12043 }\end{array}$ \\
\hline 87 & $\begin{array}{l}\text { Bereczkei, T., Voros, S., Gal, A., \& Bernath, L. (1997). Resources, attractiveness, } \\
\text { family commitment; reproductive decisions in human mate choice. Ethology, 103 (8), } \\
\text { 681-699. DOI: 10.1111/j.1439-0310.1997.tb00178.x }\end{array}$ \\
\hline 88 & $\begin{array}{l}\text { Little, A. C., Burt, D. M., Penton-Voak, I. S., \& Perrett, D. I. (2001). Self-perceived } \\
\text { attractiveness influences human female preferences for sexual dimorphism and } \\
\text { symmetry in male faces. Proceedings of the Royal Society of London B: Biological } \\
\text { Sciences, } 268 \text { (1462), 39-44. DOI: } 10.1098 / \mathrm{rspb} .2000 .1327\end{array}$ \\
\hline 89 & $\begin{array}{l}\text { Jones, B. C., Little, A. C., Boothroyd, L., Feinberg, D. R., Cornwell, R. E., DeBruine, L. } \\
\text { M., Roberts, C. S., Penton-Voak, I. S., Law Smith, M. J., Moore, F. R., et al., (2005). } \\
\text { Women's physical and psychological condition independently predict their preference } \\
\text { for apparent health in faces. Evolution and Human Behavior, } 26(6), 451-457 . \text { DOI: } \\
\text { 10.1016/j.evolhumbehav.2005.05.001 }\end{array}$ \\
\hline 90 & $\begin{array}{l}\text { Gangestad, S. W., \& Thornhill, R. (1997). The evolutionary psychology of extrapair } \\
\text { sex: The role of fluctuating asymmetry. Evolution and Human Behavior, 18(2), 69-88. } \\
\text { DOI: } 10.1016 / S 1090-5138(97) 00003-2\end{array}$ \\
\hline 91 & $\begin{array}{l}\text { Jones, B. C., DeBruine, L. M., Little, A. C., Conway, C. A., Welling, L. L., \& Smith, F. } \\
\text { (2007). Sensation seeking and men's face preferences. Evolution and Human } \\
\text { Behavior, } 28 \text { (6), 439-446. DOI: 10.1016/j.evolhumbehav.2007.07.006 }\end{array}$ \\
\hline 92 & $\begin{array}{l}\text { Smith, F. G., Jones, B. C., \& DeBruine, L. M. (2010). Individual differences in } \\
\text { empathizing and systemizing predict variation in face preferences. Personality and } \\
\text { Individual Differences, } 49 \text { (6), 655-658. DOI: } 10.1016 / \text { j.paid.2010.05.023 }\end{array}$ \\
\hline 93 & $\begin{array}{l}\text { Welling, L. L., DeBruine, L. M., Little, A. C., \& Jones, B. C. (2009). Extraversion } \\
\text { predicts individual differences in women's face preferences. Personality and Individual }\end{array}$ \\
\hline
\end{tabular}




\begin{tabular}{|c|c|}
\hline & Differences, 478), 996-998. DOI: 10.1016/j.paid.2009.06.030 \\
\hline 94 & $\begin{array}{l}\text { Surbey, M. K., \& Brice, G. R. (2007). Enhancement of self-perceived mate value } \\
\text { precedes a shift in men's preferred mating strategy. Acta Psychologica Sinica, } 39 \text { (3), } \\
513-522 .\end{array}$ \\
\hline 95 & $\begin{array}{l}\text { Little, A. C., \& Mannion, H. (2006). Viewing attractive or unattractive same-sex } \\
\text { individuals changes self-rated attractiveness and face preferences in women. Animal } \\
\text { Behaviour, } 72(5), 981-987 . \text { DOI: } 10.1016 / \text { j.anbehav. } 2006.01 .026\end{array}$ \\
\hline 96 & $\begin{array}{l}\text { Welling, L. L., Persola, L., Wheatley, J. R., Cárdenas, R. A., \& Puts, D. A. (2013). } \\
\text { Competition and men's face preferences. Personality and Individual Differences, } 54 \\
\text { (3), 414-419. DOI: 10.1016/j.paid.2012.10.014 }\end{array}$ \\
\hline 97 & $\begin{array}{l}\text { Gorelik, G., \& Bjorklund, D. F. (2015). The Effect of Competition on Men's Self- } \\
\text { Reported Sexual Interest. Evolutionary Psychological Science, } 1 \text { (3), 141-149. DOI: } \\
\text { 10.1007/s40806-015-0016-6 }\end{array}$ \\
\hline 98 & $\begin{array}{l}\text { Marcinkowska, U. M., Dixson, B. J., Kozlov, M. V., \& Rantala, M. J. (2015). Men's } \\
\text { preferences for female facial femininity decline with age. The Journals of Gerontology } \\
\text { Series B: Psychological Sciences and Social Sciences, gbv077. DOI: } \\
\text { 10.1093/geronb/gbv077 }\end{array}$ \\
\hline 99 & $\begin{array}{l}\text { Limoncin, E., Ciocca, G., Gravina, G. L., Carosa, E., Mollaioli, D., Cellerino, A., } \\
\text { Mennucci, A., Di Sante, S., Lenzi, A., \& Jannini, E. A. (2015). Pregnant Women's } \\
\text { Preferences for Men's Faces Differ Significantly from Nonpregnant Women. The journal } \\
\text { of sexual medicine,12 (5), 1142-1151.DOI: 10.1111/jsm.12849 }\end{array}$ \\
\hline 100 & $\begin{array}{l}\text { Little, A. C., Saxton, T. K., Roberts, S. C., Jones, B. C., DeBruine, L. M., Vukovic, J., } \\
\text { Perrett, D. I., Feinberg, D. R., \& Chenore, T. (2010). Women's preferences for } \\
\text { masculinity in male faces are highest during reproductive age range and lower around } \\
\text { puberty and post-menopause. Psychoneuroendocrinology, } 35 \text { (6), 912-920. DOI: } \\
\text { 10.1016/j.psyneuen.2009.12.006 }\end{array}$ \\
\hline 101 & $\begin{array}{l}\text { Gray, P. B., Kahlenberg, S. M., Barrett, E. S., Lipson, S. F., \& Ellison, P. T. (2002). } \\
\text { Marriage and fatherhood are associated with lower testosterone in males. Evolution } \\
\text { and Human Behavior, } 23 \text { (3), 193-201. DOI: 10.1016/S1090-5138(01)00101-5 }\end{array}$ \\
\hline 102 & $\begin{array}{l}\text { Gettler, L. T., McDade, T. W., Feranil, A. B., \& Kuzawa, C. W. (2011). Longitudinal } \\
\text { evidence that fatherhood decreases testosterone in human males. Proceedings of the } \\
\text { National Academy of Sciences, } 108 \text { (39), 16194-16199. DOI: } \\
\text { 10.1073/pnas.1105403108 }\end{array}$ \\
\hline 103 & $\begin{array}{l}\text { van Anders, S. M., \& Watson, N. V. (2006). Relationship status and testosterone in } \\
\text { North American heterosexual and non-heterosexual men and women: Cross-sectional } \\
\text { and longitudinal data. Psychoneuroendocrinology, } 31 \text { (6), 715-723. DOI: } \\
\text { 10.1016/j.psyneuen.2006.01.008 }\end{array}$ \\
\hline
\end{tabular}




\begin{tabular}{|c|c|}
\hline 104 & $\begin{array}{l}\text { Alvergne, A., Faurie, C., \& Raymond, M. (2009). Variation in testosterone levels and } \\
\text { male reproductive effort: Insight from a polygynous human population. Hormones and } \\
\text { Behavior, } 56(5), 491-497 . \text { DOI: } 10.1016 / \text { j.yhbeh.2009.07.013 }\end{array}$ \\
\hline 105 & $\begin{array}{l}\text { McIntyre, M., Gangestad, S. W., Gray, P. B., Chapman, J. F., Burnham, T. C., } \\
\text { O'Rourke, M. T., \& Thornhill, R. (2006). Romantic involvement often reduces men's } \\
\text { testosterone levels--but not always: the moderating role of extrapair sexual } \\
\text { interest. Journal of Personality and Social Psychology, } 91 \text { (4), 642. DOI: } \\
\text { 10.1037/0022-3514.91.4.642 }\end{array}$ \\
\hline 106 & $\begin{array}{l}\text { Johnston, V. S., Hagel, R., Franklin, M., Fink, B., \& Grammer, K. (2001). Male facial } \\
\text { attractiveness: Evidence for hormone-mediated adaptive design. Evolution and human } \\
\text { behavior, } 22 \text { (4), 251-267. DOI: 10.1016/S1090-5138(01)00066-6 }\end{array}$ \\
\hline 107 & $\begin{array}{l}\text { Roney, J. R., \& Simmons, Z. L. (2013). Hormonal predictors of sexual motivation in } \\
\text { natural menstrual cycles. Hormones and Behavior, 63 (4), 636-645. DOI: } \\
\text { 10.1016/j.yhbeh.2013.02.013 }\end{array}$ \\
\hline 108 & $\begin{array}{l}\text { Eisenbruch, A. B., Simmons, Z. L., \& Roney, J. R. (2015). Lady in Red: Hormonal } \\
\text { Predictors of Women's Clothing Choices. Psychological Science, } 26 \text { (8), 1332-1338. } \\
\text { DOI: } 10.1177 / 0956797615586403\end{array}$ \\
\hline 109 & $\begin{array}{l}\text { Welling, L. L., Jones, B. C., DeBruine, L. M., Smith, F. G., Feinberg, D. R., Little, A. C., } \\
\text { \& Al-Dujaili, E. A. (2008). Men report stronger attraction to femininity in women's faces } \\
\text { when their testosterone levels are high. Hormones and Behavior, 54(5), 703-708. } \\
\text { DOI: } 10.1016 / \text { j.yhbeh.2008.07.012 }\end{array}$ \\
\hline 110 & $\begin{array}{l}\text { Jones, B. C., Fincher, C. L., Welling, L. L., Little, A. C., Feinberg, D. R., Watkins, C. D., } \\
\text { Al-Dujaili, E. A. S., \& DeBruine, L. M. (2013). Salivary cortisol and pathogen disgust } \\
\text { predict men's preferences for feminine shape cues in women's faces. Biological } \\
\text { Psychology, } 92 \text { (2), 233-240. DOI: 10.1016/j.biopsycho.2012.11.014 }\end{array}$ \\
\hline 111 & $\begin{array}{l}\text { oney, J. R., \& Simmons, Z. L. (2008). Women's estradiol predicts preference for facial } \\
\text { les of men's testosterone. Hormones and Behavior, } 53 \text { (1), 14-19. DOI: } \\
.1016 / \text { j.yhbeh.2007.09.008 }\end{array}$ \\
\hline 112 & $\begin{array}{l}\text { Roney, J. R., Simmons, Z. L., \& Gray, P. B. (2011). Changes in estradiol predict within- } \\
\text { women shifts in attraction to facial cues of men's testosterone. } \\
\text { Psychoneuroendocrinology, } 36 \text { (5), 742-749. DOI: } 10.1016 / \text { j.psyneuen.2010.10.010 }\end{array}$ \\
\hline 113 & $\begin{array}{l}\text { Bobst, C., Sauter, S., Foppa, A., \& Lobmaier, J. S. (2014). Early follicular testosterone } \\
\text { level predicts preference for masculinity in male faces-But not for women taking } \\
\text { hormonal contraception. Psychoneuroendocrinology, 41,142-150. DOI: } \\
\text { 10.1016/j.psyneuen.2013.12.012 }\end{array}$ \\
\hline 114 & B. C., $\mathrm{Vul}$ \\
\hline
\end{tabular}




\begin{tabular}{|c|c|}
\hline & $\begin{array}{l}\text { eer-aged faces. Biological psychology, } 87 \text { (3), 453-455. DOI: } \\
\text { bi.org/10.1016/j.biopsycho.2011.04.004 }\end{array}$ \\
\hline 115 & $\begin{array}{l}\text { Jones, B. C., Hahn, A. C., Fisher, C. I., Wang, H., Kandrik, M., Han, C., Fasolt, V., } \\
\text { Morrison, D., Lee, A. J., Holzleitner, I. J., Roberts, S. C., Little, A. C., \& DeBruine, L. } \\
\text { M. (2017). Women's Preferences For Facial Masculinity Are Not Related To Their } \\
\text { Hormonal Status. BioRxiv, 136549. DOI: 10.1101/136549 }\end{array}$ \\
\hline 116 & $\begin{array}{l}\text { Regan, P. C., Levin, L., Sprecher, S., Christopher, F. S., \& Gate, R. (2000). Partner } \\
\text { preferences: What characteristics do men and women desire in their short-term sexual } \\
\text { and long-term romantic partners? Journal of Psychology \& Human Sexuality, } 1 \text { 23), 1- } \\
\text { 21. DOI: 10.1300/J056v12n03_01 }\end{array}$ \\
\hline 117 & $\begin{array}{l}\text { Stewart, S., Stinnett, H., \& Rosenfeld, L. B. (2000). Sex differences in desired } \\
\text { characteristics of short-term and long-term relationship partners. Journal of Social and } \\
\text { Personal Relationships, } 17(6), 843-853 \text {. DOI: } 10.1177 / 0265407500176008\end{array}$ \\
\hline 118 & $\begin{array}{l}\text { Schmitt, D. P. (2014). Evaluating evidence of mate preference adaptations: How do we } \\
\text { really know what Homo sapiens sapiens really want? In V. A. Weekes-Shackelford \& T. } \\
\text { K. Shackelford (Eds.), Evolutionary perspectives on human sexual psychology and } \\
\text { behavior (pp. 3-39). New York: Springer. }\end{array}$ \\
\hline 119 & $\begin{array}{l}\text { Owen, J., \& Fincham, F. D. (2011). Effects of gender and psychosocial factors on } \\
\text { "friends with benefits" relationships among young adults. Archives of sexual } \\
\text { behavior, } 40 \text { (2), 311-320. DOI: 10.1007/s10508-010-9611-6 }\end{array}$ \\
\hline 120 & $\begin{array}{l}\text { Kenrick, D. T., Sadalla, E. K., Groth, G., \& Trost, M. R. (1990). Evolution, traits, and } \\
\text { the stages of human courtship: Qualifying the parental investment model. Journal of } \\
\text { Personality, } 58 \text { (1), 97-116. DOI: 10.1111/j.1467-6494.1990.tb00909.x }\end{array}$ \\
\hline 121 & $\begin{array}{l}\text { Gangestad, S. W., \& Buss, D. M. (1993). Pathogen prevalence and human mate } \\
\text { preferences. Ethology and Sociobiology, } 14(2), 89-96 . \text { DOI: 10.1016/0162- } \\
\text { 3095(93)90009-7 }\end{array}$ \\
\hline 122 & $\begin{array}{l}\text { DeBruine, L. M., Jones, B. C., Crawford, J. R., Welling, L. L., \& Little, A. C. (2010). The } \\
\text { health of a nation predicts their mate preferences: cross-cultural variation in women's } \\
\text { preferences for masculinized male faces. Proceedings of the Royal Society of London } \\
\text { B: Biological Sciences, } 277(1692), 2405-2410 . \text { DOI: } 10.1098 / \text { rspb.2009.2184 }\end{array}$ \\
\hline 123 & $\begin{array}{l}\text { Brooks, R., Scott, I. M., Maklakov, A. A., Kasumovic, M. M., Clark, A. P., \& Penton- } \\
\text { Voak, I. S. (2011). National income inequality predicts women's preferences for } \\
\text { masculinized faces better than health does. Proceedings of the Royal Society of } \\
\text { London B: Biological Sciences, } 278(1707), 810-812 \text {. DOI: } 10.1098 / \mathrm{rspb} .2010 .0964\end{array}$ \\
\hline 124 & $\begin{array}{l}\text { Marcinkowska, U. M., Kozlov, M. V., Cai, H., Contreras-Garduño, J., Dixson, B. J., } \\
\text { Oana, G. A., Kaminski, G., Li., N. P., Lyons, M. T., Onyishi, I. E., et al. (2014). Cross- } \\
\text { cultural variation in men's preference for sexual dimorphism in women's faces. Biology }\end{array}$ \\
\hline
\end{tabular}




\begin{tabular}{|c|c|}
\hline & Letters, 10 (4), 20130850. DOI: 10.1098/rsbl.2013.0850 \\
\hline 125 & $\begin{array}{l}\text { McGraw, K. J. (2002). Environmental predictors of geographic variation in human } \\
\text { mating preferences. Ethology, } 108 \text { (4), 303-317. DOI: } 10.1046 / j .1439- \\
0310.2002 .00757 . x\end{array}$ \\
\hline 126 & $\begin{array}{l}\text { Eagly, A. H., \& Wood, W. (1999). The origins of sex differences in human behavior: } \\
\text { Evolved dispositions versus social roles. American Psychologist, } 54(6), 408-423 . \text { DOI: } \\
\text { 10.1037/0003-066X.54.6.408 }\end{array}$ \\
\hline 127 & $\begin{array}{l}\text { Moore, F. R., Cassidy, C., Smith, M. J. L., \& Perrett, D. I. (2006). The effects of female } \\
\text { control of resources on sex-differentiated mate preferences. Evolution and Human } \\
\text { Behavior, } 27 \text { (3), 193-205. DOI: 10.1016/j.evolhumbehav.2005.08.003 }\end{array}$ \\
\hline 128 & $\begin{array}{l}\text { Stone, E. A., Shackelford, T. K., \& Buss, D. M. (2008). Socioeconomic development } \\
\text { and shifts in mate preferences. Evolutionary Psychology, 6 (3), 447-455. DOI: } \\
10.1177 / 147470490800600309\end{array}$ \\
\hline 129 & $\begin{array}{l}\text { Zentner, M., \& Mitura, K. (2012). Stepping out of the caveman's shadow: nations' } \\
\text { gender gap predicts degree of sex differentiation in mate preferences. Psychological } \\
\text { Science, } 23(10), 1176-1185 . \text { DOI: } 10.1177 / 0956797612441004\end{array}$ \\
\hline 130 & $\begin{array}{l}\text { Schmitt, D. P. (2012). When the difference is in the details: A critique of Zentner and } \\
\text { Mitura (2012) "Stepping out of the caveman's shadow: Nations' gender gap predicts } \\
\text { degree of sex differentiation in mate preferences". Evolutionary Psychology, 10 (4), } \\
\text { 720-726. DOI: } 10.1177 / 147470491201000406\end{array}$ \\
\hline 131 & $\begin{array}{l}\text { Kim, K., \& Smith, P. K. (1998). Retrospective survey of parental marital relations and } \\
\text { child reproductive development. International Journal of Behavioral Development, } 22 \\
\text { (4), 729-751. DOI: } 10.1080 / 016502598384144\end{array}$ \\
\hline 132 & $\begin{array}{l}\text { Belsky, J., Steinberg, L., \& Draper, P. (1991). Childhood experience, interpersonal } \\
\text { development, and reproductive strategy: An evolutionary theory of socialization. Child } \\
\text { Development, } 62 \text { (4), 647-670. DOI: } 10.1111 / \mathrm{j} .1467-8624.1991 . t b 01558 . x\end{array}$ \\
\hline 133 & $\begin{array}{l}\text { Schmitt, D. P. (2005). Is short-term mating the maladaptive result of insecure } \\
\text { attachment? A test of competing evolutionary perspectives. Personality and Social } \\
\text { Psychology Bulletin, } 31(6), 747-768 \text {. DOI: } 10.1177 / 0146167204271843\end{array}$ \\
\hline 134 & $\begin{array}{l}\text { Schacht, R., \& Mulder, M. B. (2015). Sex ratio effects on reproductive strategies in } \\
\text { humans. Open Science, 2(1), 140402. DOI: } 10.1098 / \text { rsos. } 140402 .\end{array}$ \\
\hline 135 & $\begin{array}{l}\text { Marlowe, F. W. (2003). The mating system of foragers in the standard cross-cultural } \\
\text { sample. Cross-Cultural Research, 37(3), 282-306. DOI: } 10.1177 / 1069397103254008\end{array}$ \\
\hline 136 & $\begin{array}{l}\text { Lee, A. J., \& Zietsch, B. P. (2011). Experimental evidence that women's mate } \\
\text { preferences are directly influenced by cues of pathogen prevalence and resource }\end{array}$ \\
\hline
\end{tabular}




\begin{tabular}{|c|c|}
\hline & scarcity. Biology Letters, 7(6), 892-895. DOI: 10.1098/rsbl.2011.0454 \\
\hline 137 & $\begin{array}{l}\text { Little, A. C., DeBruine, L. M., \& Jones, B. C. (2011). Exposure to visual cues of } \\
\text { pathogen contagion changes preferences for masculinity and symmetry in opposite-sex } \\
\text { faces. Proceedings of the Royal Society of London B: Biological Sciences, 278(1714), } \\
\text { 2032-2039. DOI: } 10.1098 / \mathrm{rspb} .2010 .1925\end{array}$ \\
\hline 138 & $\begin{array}{l}\text { Little, A. C., DeBruine, L. M., \& Jones, B. C. (2013). Environment contingent } \\
\text { preferences: Exposure to visual cues of direct male-male competition and wealth } \\
\text { increase women's preferences for masculinity in male faces. Evolution and Human } \\
\text { Behavior, 34 (3), 193-200. DOI: 10.1016/j.evolhumbehav.2012.11.008 }\end{array}$ \\
\hline 139 & $\begin{array}{l}\text { Moss, J. H., \& Maner, J. K. (2016). Biased sex ratios influence fundamental aspects of } \\
\text { human mating. Personality and Social Psychology Bulletin, } 42 \text { (1), 72-80. DOI: } \\
\text { 10.1177/0146167215612744 }\end{array}$ \\
\hline 140 & $\begin{array}{l}\text { Marzoli, D., Moretto, F., Monti, A., Tocci, O., Roberts, S. C., \& Tommasi, L. (2013). } \\
\text { Environmental influences on mate preferences as assessed by a scenario manipulation } \\
\text { experiment. PLOS ONE, } 8(9) \text {, e74282. DOI: } 10.1371 / \text { journal.pone.0074282 }\end{array}$ \\
\hline 141 & $\begin{array}{l}\text { Baize, H. R., \& Schroeder, J. E. (1995). Personality and mate selection in personal ads: } \\
\text { Evolutionary preferences in a public mate selection process. Journal of Social Behavior } \\
\text { and Personality, } 10(3), 517-536 .\end{array}$ \\
\hline 142 & $\begin{array}{l}\text { Pawlowski, B., \& Koziel, S. (2002). The impact of traits offered in personal } \\
\text { advertisements on response rates. Evolution and Human Behavior, } 23(2), 139-149 . \\
\text { DOI: } 10.1016 / S 1090-5138(01) 00092-7\end{array}$ \\
\hline 143 & $\begin{array}{l}\text { Greenlees, I. A., \& McGrew, W. C. (1994). Sex and age differences in preferences and } \\
\text { tactics of mate attraction: Analysis of published advertisements. Ethology and } \\
\text { Sociobiology, 15(2), 59-72. DOI: } 10.1016 / 0162-3095(94) 90017-5\end{array}$ \\
\hline 144 & $\begin{array}{l}\text { Udry, J. R., \& Eckland, B. K. (1984). Benefits of being attractive: Differential payoffs } \\
\text { for men and women. Psychological Reports, } 54(1), 47-56 . \text { DOI: } \\
\text { 10.2466/pr0.1984.54.1.47 }\end{array}$ \\
\hline 145 & $\begin{array}{l}\text { Kenrick, D. T., \& Keefe, R. C. (1992). Age preferences in mates reflect sex differences } \\
\text { in human reproductive strategies. Behavioral and Brain Sciences, 15(01), 75-91. DOI: } \\
10.1017 / S 0140525 X 00067595\end{array}$ \\
\hline 146 & $\begin{array}{l}\text { Zeifman, D. M., \& Ma, J. E. (2013). Experimental examination of women's selection } \\
\text { criteria for sperm donors versus life partners. Personal Relationships, } 20 \text { (2), 311-327. } \\
\text { DOI: } 10.1111 / \text { j.1475-6811.2012.01409.x }\end{array}$ \\
\hline 147 & $\begin{array}{l}\text { Van Dongen, S., \& Gangestad, S. W. (2011). Human fluctuating asymmetry in relation } \\
\text { to health and quality: A meta-analysis. Evolution and Human behavior, } 32 \text { (6), 380- } \\
\text { 398. DOI: } 10.1016 / \text { j.evolhumbehav.2011.03.002 }\end{array}$ \\
\hline
\end{tabular}




\begin{tabular}{|c|c|}
\hline 148 & $\begin{array}{l}\text { Montoya, R. M. (2008). I'm hot, so I'd say you're not: The influence of objective } \\
\text { physical attractiveness on mate selection. Personality and Social Psychology } \\
\text { Bulletin, } 34(10), 1315-1331 \text {. DOI: } 10.1177 / 0146167208320387\end{array}$ \\
\hline 149 & $\begin{array}{l}\text { Chu, S., Hardaker, R., \& Lycett, J. E. (2007). Too good to be 'true'? The handicap of } \\
\text { high socio-economic status in attractive males. Personality and Individual } \\
\text { Differences, } 42 \text { (7), 1291-1300. DOI: } 10.1016 / \text { j.paid.2006.10.007 }\end{array}$ \\
\hline 150 & $\begin{array}{l}\text { Schmitt, D.P., \& } 121 \text { members of the International Sexuality Description Project } \\
\text { (2004). Patterns and universals of mate poaching across } 53 \text { nations: The effects of } \\
\text { sex, culture, and personality on romantically attracting another person's } \\
\text { partner. Journal of Personality and Social Psychology, } 86(4), 560-584 \text {. DOI: } \\
\text { 10.1037/0022-3514.86.4.560 }\end{array}$ \\
\hline 151 & $\begin{array}{l}\text { Apostolou, M. (2007). Sexual selection under parental choice: The role of parents in } \\
\text { the evolution of human mating. Evolution and Human Behavior, } 28(6), 403-409 . \text { DOI: } \\
10.1016 / j . \text { evolhumbehav.2007.05.007 }\end{array}$ \\
\hline 152 & $\begin{array}{l}\text { Collins, J., Baer, B., \& Weber, E. J. (2015). Sexual selection, conspicuous consumption } \\
\text { and economic growth. Journal of Bioeconomics, 17(2), 189-206. DOI: } \\
10.1007 / \text { s10818-015-9200-9 }\end{array}$ \\
\hline 153 & $\begin{array}{l}\text { Baker, M. D., \& Maner, J. K. (2009). Male risk-taking as a context-sensitive signaling } \\
\text { device. Journal of Experimental Social Psychology, } 45 \text { (5), 1136-1139. DOI: } \\
\text { 10.1016/j.jesp.2009.06.006 }\end{array}$ \\
\hline 154 & $\begin{array}{l}\text { Hone, L. S., Carter, E. C., \& McCullough, M. E. (2013). Drinking games as a venue for } \\
\text { sexual competition. Evolutionary Psychology, } 11 \text { (4), 889-906. DOI: } \\
10.1177 / 147470491301100413\end{array}$ \\
\hline 155 & $\begin{array}{l}\text { Iredale, W., Van Vugt, M., \& Dunbar, R. (2008). Showing off in humans: Male } \\
\text { generosity as a mating signal. Evolutionary Psychology, 6 (3), 386-392. DOI: } \\
10.1177 / 147470490800600302\end{array}$ \\
\hline 156 & $\begin{array}{l}\text { Gildersleeve, K., Haselton, M. G., \& Fales, M. R. (2014). Meta-analyses and p-curves } \\
\text { support robust cycle shifts in women's mate preferences: reply to Wood and Carden } \\
\text { (2014) and Harris, Pashler, and Mickes (2014). Psychological bulletin, 140(5), 1272- } \\
\text { 1280. DOI: } 10.1037 / a 0037714\end{array}$ \\
\hline 157 & $\begin{array}{l}\text { Wood, W., \& Carden, L. (2014). Elusiveness of menstrual cycle effects on mate } \\
\text { preferences: Comment on Gildersleeve, Haselton, and Fales (2014). Psychological } \\
\text { Bulletin, } 140(5), 1265-1271 . \text { DOI: } 10.1037 / a 0036722\end{array}$ \\
\hline 158 & $\begin{array}{l}\text { Lee, A. J., Brooks, R. C., Potter, K. J., \& Zietsch, B. P. (2015). Pathogen disgust } \\
\text { sensitivity and resource scarcity are associated with mate preference for different } \\
\text { waist-to-hip ratios, shoulder-to-hip ratios, and body mass index. Evolution and Human } \\
\text { Behavior, } 36(6) \text {, 480-488. DOI: 10.1016/j.evolhumbehav.2015.07.002 }\end{array}$ \\
\hline
\end{tabular}


Little, A. C. (2014). Condition dependent and infection dependent mate preferences in women. Animal Behavior and Cognition, 1 (3), 423-433. DOI:

159 10.12966/abc.08.14.2014 